\title{
Physiological properties of protein hydrolysate from tuna cooking drip
}

\author{
J. Choi \\ Department of Biotechnology and Bioengineering, Chonnam National University, Gwang-ju, South Korea
}

Tuna is one of the largest commercially canned fishery products in the world. Annually, more than 4 million metric tons of tuna are harvested worldwide, and approximately 3 million tons of canned tuna are produced. Steam cooking is an important method for processing canned tuna, during which a large amount of condensed water, called cooking drip, is obtained as a by-product ${ }^{(1)}$. Cooking drip is a rich source of nutritionally valuable proteins, but it is being wasted. It has been reported that various peptides or hydrolysates derived from seafood proteins possess better health benefits in comparison with crude protein ${ }^{(2)}$. Gamma irradiation has been used to decontaminate the food and agricultural products, but hydrolysis process with irradiation had several advantages including simple processing with a short hydrolysis time, simultaneous sterilization, and no additive catalysts. Therefore, in this study, radiation process was used to hydrolyze the protein from tuna cooking drip.

The cooking drip of Thunnus thynnus (protein content determined by the bicinchoninic acid method, $2.1 \mathrm{~g} / \mathrm{L}$ ) was obtained from DongWon Fisheries Co. (Seoul, Republic of Korea). The cooking drip was filtered, and then precipitated with trichloroacetic acid. The freeze-dried protein sample was resuspended in distilled water to constitute the original concentration, and then gamma irradiated.

We observed that the main proteins with high molecular weights of $200 \mathrm{kDa}, 100 \mathrm{kDa}$, and $65 \mathrm{kDa}$ were degraded by the gamma irradiation. The degradation of proteins was dependent on the absorbed dose of gamma rays. When the dose was increased, the high molecular weight proteins were degraded more severely. The degree of hydrolysis (DH) was measured after irradiation. When the absorbed doses were $10 \mathrm{kGy}, 30 \mathrm{kGy}$, and $50 \mathrm{kGy}$, the $\mathrm{DH}$ were $5.1 \%, 9.7 \%$, and $10.5 \%$, respectively.

To investigate the change of antioxidant activity by radiation hydrolysis, 2,2-diphenyl-1-picrylhydrazyl (DPPH) assay has been used. The DPPH radical scavenging activity of the cooking drip was $39.4 \%$. However, the DPPH radical scavenging activities of the hydrolysates were increased to $53.2 \%, 61.7 \%$, and $71.3 \%$ at the doses of $10 \mathrm{kGy}, 30 \mathrm{kGy}$ and $50 \mathrm{kGy}$, respectively. The inhibition of ACE activity is a major target for anti-hypertension. The angiotensin-I-converting enzyme (ACE) inhibitory activity of tuna cooking drip was about $62.7 \%$ and that of the hydrolysate irradiated at a dose of $10 \mathrm{kGy}$ was increased to $73.9 \%$. The ACE inhibitory activities of the hydrolysate increased depending on the irradiation dose, being $83.6 \%$ and $84.8 \%$ at the doses of $30 \mathrm{kGy}$ and $50 \mathrm{kGy}$, respectively. Tyrosinase inhibitors have recently become increasingly important in medicinal and cosmetic products in relation to hyperpigmentation. The tyrosinase inhibitory activity of tuna cooking drip was $31 \%$, but the activities increased in accordance with the absorbed dose. When the doses were $10 \mathrm{kGy}, 30 \mathrm{kGy}$, and $50 \mathrm{kGy}$, the tyrosinase inhibitory activities of hydrolysate were increased to $38.5 \%$, $62.1 \%$, and $63.2 \%$, respectively. These results suggest that radiation hydrolysis is a promising method for food and environmental industries.

This study was financially supported by Chonnan National University, 2013.

1. Paz DM, Ayaso ABT, De Sousa JMVB (2006) Tecnologia del Agua 26: 42-47.

2. Hsu KC, Cheng ML, Hwang JS (2007) Journal of Food and Drug Anlaysis 15: 169-173. 